\title{
Community's knowledge, attitude, and misperception towards COVID-19: a future demand to prevent advanced wave of pandemic
}

\author{
Novi MauliIna ${ }^{1,2,5}$, Nova Fajri $^{3,5}$, Rosaria Indah $^{2,5^{*}}$, Shylvana Adella ${ }^{4,5}$ \\ ${ }^{1}$ Doctoral Student, Medical Faculty, Syiah Kuala University, Aceh, Indonesia, 23111 \\ ${ }^{2}$ Medical Faculty, Syiah Kuala University, Aceh, Indonesia, 23111 \\ ${ }^{3}$ Nursing Faculty, Syiah Kuala University, Aceh, Indonesia, 23111 \\ ${ }^{4}$ Public Health Faculty, Serambi Mekkah University, Aceh, Indonesia, 23123 \\ ${ }^{5}$ IMANI-PROKAMI (Islamic Medical Association and Network of Indonesia-Perhimpunan Profesi Kesehatan Muslim Indonesia), \\ Aceh, Indonesia
}

\begin{abstract}
Coronavirus disease 19 is currently a global health threat. Viral spread prevention is essential as a feasible intervention strategy. The aim of this study was to determine the level of community knowledge, attitude, and perception towards Covid-19 in Aceh province. An electronic questionnaire was shared with 1,058 participants in the Covid-19 seminars organized by IMANI-PROKAMI Aceh Chapter (Islamic Medical Association and Network of Indonesia - Perhimpunan Profesi Kesehatan Muslim Indonesia), which were held between August 30th to Sept 20th, 2020. The questionnaire collected demographic data as well as data related to knowledge, perception, and attitude towards Covid-19 prevention. There were 1,058 survey participants, 841 (79.5\%) of them were women, $366(34.6 \%)$ were between 26 and 35 of age, $705(66.6 \%)$ had a college degree and $540(51.0 \%)$ were government employees. Most of participants had good knowledge and attitude about Covid-19 and its prevention. However, $44.1 \%$ of participants believed that the virus was created in research laboratories, as a result of conspiration (35.4\%), and related to political issues $(20 \%)$. They doubted the accuracy of Covid-19 diagnostic test $(52.5 \%)$ and effectiveness of vaccines (28.2\%). The results show multiple cases of misinformation around Covid19. Therefore, stakeholders need to counteract the community misperception towards disease by a transparent and strategic collaboration between society, government, and media, to increase positive perception, attitude, and practice of the community toward Covid19's prevention.
\end{abstract}

\section{Introduction}

The unprecedented pandemic of Covid-19 [1] has altered the way public live. The total confirmed cases and deaths worldwide increased at an alarming rate [2]. After 17 months since the first case of Covid-19 in Hubei Province, China, Indonesia bears a heavy burden, counting the highest case prevalence and fatality rate in Southeast Asia. Catastrophic damages in public health, economic and social stability has been severely affected the country. $[3,4]$

In order to develop the herd immunity, vaccination, social distancing, and good critical care services remain best strategies to decrease mortality. [5,6] However, as the number of people infected with COVID-19 grows, Indonesia and many other countries are, or will be, overburdening their health-care systems. Strengthening the non-pharmaceutical intervention including $5 \mathrm{M}$ (Wearing mask, washing hands with soap, social distancing, avoiding the crowd and mobility restriction) in Indonesia is an essential effort to decrease casualties and flatten the curve. [6-8] Nevertheless, one of the key factors influencing these strategies is the public active engagement and compliance with the measures. [8-10]

Public compliance depends on how people act toward risk-seeking or risk-avoiding actions, called public risk perception. Individual risk perception was influenced toward the threat. $[11,12]$ Besides, individual knowledge, attitude, and practices will shape their readiness to fight against the disease, in line with societal conformity of the proposed regulations. [11-13]

As the most devastating effects of Covid-19 spread globally, it causes confusion, anxiety and fear among the public. $[13,14]$ In some places, the existence of the virus is doubted, since the virus is invisible, abstract, and some people cannot really accept that having flu will threaten their lives. [14,15] They think that this pandemic benefits health care workers (HCWs). But, absurdly, in some places, they attacked health care workers for not allowing them to take care of the deceased body of their family after the death. [14,15]

Social media played a main role in escalating covid19 to vaccine-related fake news. [16] Misinformation regarding vaccines in social media generated a fear and

\footnotetext{
${ }^{*}$ Corresponding author: rosaria.indah@unsyiah.ac.id
} 
hesitancy toward vaccine administration. [17] Vaccine safety and effectivity were misperceived daily in the media, augmentate the hesitancy and activate the antivaccine movement in society. $[18,19]$

As time and research evolve, covid-19 related facts are growing. However, fake news is also increasing in Indonesian communities. Parallel with frequent social media use, this fake news is outspreading quickly. [20] Yet, there is scant research on what kind of misinformation is influencing people's perception toward Covid19 situation. This study aimed to evaluate knowledge, attitude, and perception of Aceh community during the coronavirus pandemic. The result of this study may inform future strategies focusing on public preparedness toward pandemic situation.

\section{Methods}

\subsection{Study design and sample}

This cross-sectional study was conducted involving 1,058 respondents participating in virtual seminar about Covid-19 provided by IMANI-PROKAMI Aceh Chapter (Islamic Medical Association and Network of Indonesia - Perhimpunan Profesi Kesehatan Muslim Indonesia). The seminars were held weekly for four weeks, from August 30th until September $20^{\text {th }}, 2020$. A link to the survey was distributed via Zoom chat box, right before the seminars started.

\subsection{Measurement tool and data analysis}

The self-reported questionnaire was developed, according to the COVID-19 prevention guidelines at a community level. The questionnaire was designed in Bahasa Indonesia, inviting respondents living in Aceh province, aged 18 years or older, and agree to participate completing the questionnaire.

The questionnaire consisted of four primary sections. The first section gathered information on respondents' sociodemographic characteristics, including age, gender, education level, work status, and region of residence. The second section assessed participants' knowledge of Covid-19. This section included 12 items on modes of transmission, clinical symptoms, disease risks, prevention measures, and treatments. The third section assessed participants' attitudes by asking their agreement toward statements about Covid-19. The final section of the questionnaire assessed respondents' misperception towards Covid-19.

\subsection{Independent variables}

For sociodemographic variables, gender was coded as one for men, and zero for women. The age variable was divided into categories: $18-25,26-35,36-45,46-55,55$ 65 , and $>65$.

Educational levels were categorized into high school or below, college/university degree, and postgraduate degree.
Occupational data were grouped into students, government employee, non-government employee, selfemployed, and un-employed.

We also obtained the data on the location of participants, which were residing in 23 districts in Aceh province: Banda Aceh, Aceh Besar, Sabang, Pidie, Pidie Jaya, Bireun, Aceh Utara, Lhokseumawe, Aceh Timur, Langsa, Aceh Tamiang, Aceh Tengah, Bener Meriah, Gayo Lues, Aceh Tenggara, Aceh Jaya, Aceh Barat, Nagan Raya, Aceh Barat Daya, Aceh Selatan, Simeulue, Subulussalam, and Singkil.

\subsection{Dependent variables}

Respondents were asked to respond to knowledge questions as either true or false, with an additional "I have no idea" option. The incorrect and additional response were given a score of zero, and correct answers were assigned a score of one. The total score for knowledge ranged from zero to 12 , with high scores indicating better knowledge of COVID-19. Scores of 7 and above were categorized as good, and scores of 6 and below were categorized as poor.

In the section on attitudes, scores were calculated based on the respondents' answers. Total scores ranged from zero to four, with high scores indicating positive attitudes.

In the section on perception related covid-19 statements, respondents were asked to respond "yes" or "no" to the items. A score of one was given to answers that reflected good perception, and a score of zero was given for answers that reflected false statement. The total score ranged from zero to eleven, with high scores indicating better perception.

\subsection{Analysis methods}

Univariate analysis was used to analyze demographic data. Chi-Square tests was used to differentiate between good and poor knowledge, good and poor attitude and positive and negative perception related Covid-19. All analyses utilized SPSS Software.

\section{Results}

A total of 1,058 responses were recorded in the study. One participant could only give one response. All the participants were above 18 years old and Aceh origin. The total sample consist of 841 (79.5\%) female participants and $217(20.5 \%)$ were male. A large portion of the participants $(34.6 \%)$ aged between 26 and 35 . More than half of the sample $(66.6 \%)$ had a college or university degree. In terms of work status, 540 (51.0\%) were government employees and 50 (4.7\%) were selfemployed. Participants came from different regions in Aceh and the highest portion, 334 of them (31.5\%) were residing in Banda Aceh. 
Table 1. Demographic Characteristic of Participants.

\begin{tabular}{|c|c|c|}
\hline Variable & $\mathrm{N}$ & $\%$ \\
\hline $\begin{array}{l}\text { Gender } \\
\text { Male } \\
\text { Female } \\
\end{array}$ & $\begin{array}{l}217 \\
841 \\
\end{array}$ & $\begin{array}{l}20.5 \\
79.5 \\
\end{array}$ \\
\hline $\begin{array}{l}\text { Age } \\
18-25 \\
26-35 \\
36-45 \\
46-55 \\
56-65 \\
>65 \\
\end{array}$ & $\begin{array}{c}280 \\
366 \\
320 \\
76 \\
14 \\
2 \\
\end{array}$ & $\begin{array}{c}26.5 \\
34.6 \\
30.2 \\
7.1 \\
1.3 \\
0.1\end{array}$ \\
\hline $\begin{array}{l}\text { Education } \\
\text { High School } \\
\text { Bachelor's Degree } \\
\text { Post Graduate Degree } \\
\end{array}$ & $\begin{array}{l}172 \\
705 \\
181 \\
\end{array}$ & $\begin{array}{l}16.2 \\
66.6 \\
17.1 \\
\end{array}$ \\
\hline $\begin{array}{l}\text { Occupation } \\
\text { Students } \\
\text { Government Employee } \\
\text { Non-Government Employee } \\
\text { Self-Employed } \\
\text { Un-employed }\end{array}$ & $\begin{array}{c}240 \\
540 \\
222 \\
\\
50 \\
102\end{array}$ & $\begin{array}{l}22.7 \\
51.0 \\
20.9 \\
4.7 \\
9.6\end{array}$ \\
\hline $\begin{array}{l}\text { Region } \\
\text { Banda Aceh } \\
\text { Aceh Besar } \\
\text { Sabang } \\
\text { Pidie } \\
\text { Pidie Jaya } \\
\text { Bireun } \\
\text { Aceh Utara } \\
\text { Lhokseumawe } \\
\text { Aceh Timur } \\
\text { Langsa } \\
\text { Aceh Tamiang } \\
\text { Aceh Tengah } \\
\text { Bener Meriah } \\
\text { Gayo Lues } \\
\text { Aceh Tenggara } \\
\text { Aceh Jaya } \\
\text { Aceh Barat } \\
\text { Nagan Raya } \\
\text { Aceh Barat Daya } \\
\text { Aceh Selatan } \\
\text { Simeulue } \\
\text { Subulussalam } \\
\text { Singkil }\end{array}$ & $\begin{array}{c}334 \\
230 \\
8 \\
37 \\
0 \\
74 \\
15 \\
41 \\
10 \\
30 \\
20 \\
57 \\
3 \\
2 \\
11 \\
11 \\
48 \\
17 \\
48 \\
15 \\
6 \\
53 \\
5\end{array}$ & $\begin{array}{l}31.5 \\
21.7 \\
0.7 \\
3.5 \\
0 \\
6.9 \\
1.4 \\
3.8 \\
0.9 \\
2.8 \\
1.8 \\
5.3 \\
0.2 \\
0.1 \\
1.0 \\
1.0 \\
4.53 \\
1.6 \\
4.5 \\
1.4 \\
0.5 \\
5.0 \\
0.4\end{array}$ \\
\hline
\end{tabular}

As shown in table 2, the average of COVID-19 knowledge score was 11.67 ( $\mathrm{SD}=0.76$, range: $4-12$ ), indicating good knowledge. The average score in attitude toward COVID-19 was 3.73 (SD $=0.51$, range: $1-4)$, indicating positive attitudes, and the average score for perception was 7.91 ( $\mathrm{SD}=2.91$, range: $0-11)$.

Table 2. Knowledge, Attitude, and Perception towards Covid-19 among participants.

\begin{tabular}{|l|c|c|c|c|}
\hline Variable & Mean & SD & Min & Max \\
\hline $\begin{array}{l}\text { Knowledge } \\
\text { Score }\end{array}$ & 11.67 & \pm 0.76 & 4 & 12 \\
\hline $\begin{array}{l}\text { Attitude } \\
\text { Score }\end{array}$ & 3.73 & \pm 0.51 & 1 & 4 \\
\hline $\begin{array}{l}\text { Perception } \\
\text { Score }\end{array}$ & 7.91 & \pm 2.91 & 0 & 11 \\
\hline
\end{tabular}

Table 3 depicts our findings about relation between community knowledge, attitude and perception towards Covid-19. There was a statistically significant correlation between knowledge and attitude. However, there was no correlation between knowledge and perception and between perception and attitude. In other words, good knowledge and attitude do not guarantee high risk perception of Covid-19.

Table 3. Relation between knowledge, attitude and perception.

\begin{tabular}{|c|c|c|c|c|c|c|c|}
\hline & \multicolumn{2}{|c|}{ Knowledge } & \multirow[t]{2}{*}{ P-value } & \multicolumn{2}{|c|}{ Perception } & \multirow{2}{*}{$\begin{array}{c}\text { P- } \\
\text { value }\end{array}$} \\
\hline & & Good & Poor & & Pos & Neg & \\
\hline \multirow[t]{2}{*}{ Attitude } & Good & 811 & 2 & \multirow[t]{2}{*}{$<0.0001$} & 410 & 401 & \multirow[t]{2}{*}{0.104} \\
\hline & Poor & 237 & 8 & & 139 & 106 & \\
\hline \multirow[t]{2}{*}{ Perception } & Pos & 542 & 7 & \multirow[t]{2}{*}{0.345} & & & \\
\hline & $\mathrm{Neg}$ & 504 & 3 & & & & \\
\hline
\end{tabular}

Table 4 shows participant's responses to misinformation towards Covid-19. Almost half of participants $(44.1 \%)$ believe that the virus was created in research laboratory, as a conspiration power (35.4\%), and a political issue $(20 \%)$. More than half of participants $(52.7 \%)$ doubted the accuracy of Covid-19 diagnostic test. They believe that positivity test of Covid-19 was aimed to benefit medical staffs and hospitals financially $(25.6 \%)$. The vaccine production was a multi-profit project was also believed by $28.2 \%$ participants.

Table 4. Community Perception towards Covid-19.

\begin{tabular}{|l|c|}
\hline \multicolumn{1}{|c|}{ Statements } & Yes (\%) \\
\hline $\begin{array}{l}\text { Covid-19 virus was deliberately created in a } \\
\text { research laboratory }\end{array}$ & $467(44.1 \%)$ \\
\hline $\begin{array}{l}\text { Covid-19 is a conspiracy created to reduce } \\
\text { the world's population }\end{array}$ & $375(35.4 \%)$ \\
\hline $\begin{array}{l}\text { Covid-19 is a political fabrication. Medical } \\
\text { personnel and lab examining Covid-19 tests } \\
\text { get a lot of benefits from this pandemic }\end{array}$ & $218(20.6 \%)$ \\
\hline $\begin{array}{l}\text { Covid-19 is a self-limiting disease. It's no } \\
\text { need for special drugs and isolation }\end{array}$ & $164(15.5 \%)$ \\
\hline $\begin{array}{l}\text { The funerals of Covid-19 patients can be } \\
\text { carried out as usual without special } \\
\text { protocols }\end{array}$ & $159(15.0 \%)$ \\
\hline $\begin{array}{l}\text { In-patient hospital, either because of } \\
\text { respiratory symptoms (fever, cough and } \\
\text { runny nose) or other diseases will be called } \\
\text { positive for Covid-19, to increase the } \\
\text { number of cases and the aid fund }\end{array}$ & $271(25.6 \%)$ \\
\hline $\begin{array}{l}\text { The creation of a Covid-19 vaccine is a } \\
\text { multi-profit project }\end{array}$ & $299(28.2 \%)$ \\
\hline $\begin{array}{l}\text { The results of diagnosis test of Covid-19 are } \\
\text { changing, so the accuracy can be doubted }\end{array}$ & $558(52.5 \%)$ \\
\hline
\end{tabular}

Table 5 shows the responses to items related to knowledge, attitude and perception towards COVID-19. As shown in the table, there was a statistically significant difference in attitudes, across gender and occupation. In sum, there is a significant corelation between attitude in gender and occupation. Perception towards Covid-19 was also has a statistically significant difference across occupations. 
Table 5. Comparison of demographic characteristics and knowledge, attitude and perception towards COVID-19.

\begin{tabular}{|c|c|c|c|c|c|c|c|}
\hline \multirow{2}{*}{\multicolumn{2}{|c|}{ Variable }} & \multicolumn{2}{|c|}{ Knowledge } & \multicolumn{2}{|c|}{ Attitude } & \multicolumn{2}{|c|}{ Perception } \\
\hline & & \multirow{3}{*}{$\begin{array}{c}\begin{array}{c}\text { Good/ } \\
\text { Poor }\end{array} \\
213 / 4 \\
835 / 6\end{array}$} & \multirow{3}{*}{$\begin{array}{c}\text { P-value } \\
0.254\end{array}$} & \multirow{3}{*}{$\begin{array}{c}\begin{array}{c}\text { Good/ } \\
\text { Poor }\end{array} \\
149 / 68 \\
664 / 177\end{array}$} & \multirow{3}{*}{$\begin{array}{c}\text { P-value } \\
0.002\end{array}$} & \multirow{3}{*}{$\begin{array}{l}\text { Pos/Neg } \\
117 / 100 \\
432 / 407\end{array}$} & \multirow{3}{*}{$\begin{array}{r}\text { P-Value } \\
0.574\end{array}$} \\
\hline \multirow{2}{*}{ Gender } & Men & & & & & & \\
\hline & Women & & & & & & \\
\hline \multirow[t]{6}{*}{ Age } & $18-25$ & $276 / 4$ & \multirow[t]{6}{*}{0.847} & $210 / 70$ & \multirow[t]{6}{*}{0.416} & $148 / 132$ & \multirow[t]{6}{*}{0.574} \\
\hline & $26-35$ & $362 / 4$ & & $284 / 82$ & & $192 / 172$ & \\
\hline & $36-45$ & $318 / 2$ & & $250 / 70$ & & $156 / 164$ & \\
\hline & $46-55$ & $76 / 0$ & & $54 / 22$ & & $43 / 33$ & \\
\hline & $56-65$ & $14 / 0$ & & $13 / 1$ & & $8 / 6$ & \\
\hline & $>65$ & $2 / 0$ & & $2 / 0$ & & $2 / 0$ & \\
\hline \multirow[t]{3}{*}{ Education Level } & High School & $171 / 1$ & \multirow[t]{3}{*}{0.666} & $132 / 40$ & \multirow[t]{3}{*}{0.745} & $90 / 82$ & \multirow[t]{3}{*}{0.981} \\
\hline & Under-graduate & $697 / 8$ & & $538 / 167$ & & $364 / 339$ & \\
\hline & Graduate & $180 / 1$ & & $143 / 38$ & & $95 / 86$ & \\
\hline \multirow[t]{5}{*}{ Occupation } & Students & $238 / 2$ & \multirow[t]{5}{*}{$>0.005$} & $183 / 57$ & \multirow[t]{5}{*}{0.002} & $127 / 113$ & \multirow[t]{5}{*}{0.029} \\
\hline & Govt Employee & $444 / 0$ & & $355 / 89$ & & $220 / 224$ & \\
\hline & $\begin{array}{l}\text { Non-Govt } \\
\text { Employee }\end{array}$ & $217 / 5$ & & $171 / 51$ & & $106 / 115$ & \\
\hline & Self-Employee & $47 / 3$ & & $27 / 23$ & & $31 / 19$ & \\
\hline & Un-employed & $102 / 0$ & & $77 / 25$ & & $65 / 36$ & \\
\hline \multirow[t]{23}{*}{ Region } & Banda Aceh & $329 / 5$ & \multirow[t]{23}{*}{0.485} & $258 / 76$ & 0.896 & $175 / 158$ & 0.485 \\
\hline & A. Besar & $229 / 1$ & & $178 / 52$ & & $127 / 103$ & \\
\hline & Sabang & $8 / 0$ & & $7 / 1$ & & $4 / 4$ & \\
\hline & Pidie & $31 / 0$ & & $28 / 3$ & & $14 / 16$ & \\
\hline & Pidie Jaya & $5 / 1$ & & $5 / 1$ & & $6 / 0$ & \\
\hline & Bireun & $73 / 1$ & & $54 / 20$ & & $41 / 33$ & \\
\hline & A. Utara & $15 / 0$ & & $13 / 2$ & & $7 / 8$ & \\
\hline & Lhokseumawe & $41 / 0$ & & $32 / 9$ & & $18 / 23$ & \\
\hline & A. Timur & $10 / 0$ & & $6 / 4$ & & $6 / 4$ & \\
\hline & Langsa & $30 / 0$ & & $23 / 7$ & & $18 / 12$ & \\
\hline & A. Tamiang & $20 / 0$ & & $17 / 3$ & & $10 / 10$ & \\
\hline & A. Tengah & $57 / 0$ & & $43 / 14$ & & $23 / 34$ & \\
\hline & Bener Meriah & $3 / 0$ & & $2 / 1$ & & $2 / 1$ & \\
\hline & Gayo Lues & $2 / 0$ & & $2 / 0$ & & $2 / 0$ & \\
\hline & A. Tenggara & $11 / 0$ & & $8 / 3$ & & $4 / 7$ & \\
\hline & A. Jaya & $11 / 0$ & & $8 / 3$ & & $5 / 6$ & \\
\hline & A. Barat & $35 / 1$ & & $27 / 9$ & & $19 / 17$ & \\
\hline & Nagan Raya & $17 / 0$ & & $14 / 3$ & & $6 / 11$ & \\
\hline & A. Barat Daya & $12 / 0$ & & $7 / 5$ & & $6 / 6$ & \\
\hline & A. Selatan & $15 / 0$ & & $12 / 3$ & & $8 / 7$ & \\
\hline & Simeulue & $6 / 0$ & & $4 / 2$ & & $3 / 3$ & \\
\hline & Subulussalam & $52 / 1$ & & $37 / 16$ & & $25 / 28$ & \\
\hline & Singkil & $5 / 0$ & & $5 / 0$ & & $3 / 2$ & \\
\hline
\end{tabular}

\section{Discussion}

This study aimed to evaluate knowledge, attitude, and perception of Aceh communities toward Covid-19. Due to the disease's serious threats, preventive measures are crucial in decreasing infection rates and controlling the disease spread. These measures are impossible to conduct without public engagement and support, which is affected by their knowledge, attitudes, perception, and practices.[21,22]

Located in the western part of Indonesia with 5.371.532 population, Aceh had a significant increase of Covid-19 prevalence in May 2021.[23] On August 27th 2021, this region had the highest positivity rate of $51.55 \%$ nationally followed by a high bed occupancy rate (BOR) for Covid-19 of 59\%, while it had been struggling with low vaccination coverage.[24,25]

The result of this study shows that most of the participants showed a good knowledge and optimistic attitude toward COVID-19. Most of them concur the virus transmission can be avoided by complying with preventive measures, applying cough etiquette, and offering social support to other community members during outbreak (table 2 and 3 ).

However, in the same time, they misperceived Covid-19 facts. Although most of the participants understand that the disease caused by virus which could be transmitted airborne by cough and sneeze, some of them believed that the virus was a conspiracy of certain parties. They believed that the virus was deliberately created in laboratories to reduce the population $(35.4 \%$ $\& 44.1 \%)$. Twenty percent of the participants thought that healthcare providers, including laboratory staff conducting Covid-19 tests obtained financial benefits from this pandemic. Furthermore, they doubted the accuracy of Covid-19 tests as they produce different results overtime. There were also misperceptions of vaccine-related facts reported by most of the 
participants (52.7\% and 28,2\%, respectively). The result concurs with findings in other studies as the belief on the myth of laboratory-produced virus was also reported elsewhere. [26-29] This interpretation raises another question: do these people believe that Covid-19 is real? Will they comply with the preventive measures and accept vaccine?

A key factor contributes to the commitment to disease prevention during outbreaks of pandemic is risk perception.[30,31] The type of information someone received may mediate the risk perception of Covid-19, whether it is an accurate information or fake one. Misinformation or lack of information may challenge risk of infection. [30-32] The interesting part to consider is that people make judgments based on their own risk perception, not on the actual risk. [31,32]

Risk perception is also related to individual background such as socio-economy status. [28] This may explain the discrepancy between knowledge and perception of Covid-19 in our findings. Most of the participants had good knowledge but good portion of them believed in misinformation around Covid-19. The latter may lead to low risk perception.

It appears that the low risk perception may lead to practices that disregard early Covid-19 symptoms. Considering the strong infectivity of Covid-19 and the symptoms of the disease [29], some of practices based on low-risk perception may lead to recurrent episode of case outbreaks. Furthermore, the rejection toward vaccination is related to the myth of the laboratoryproduced virus and this may lead to low vaccination coverage. $[33,34]$ Therefore, health campaigns should be well designed to address the misinformation (a.k.a. hoaxes) related to Covid-19. [30]

This study calls for stronger efforts to improving public risk perception in disease prevention, which may include stronger collaboration between society, government, and the media. [35] To increase public risk perception, public health institutions may utilize massive promotion in social media in an transparent, strategic, and proactive manner. In addition, larger investments should also involve efforts in increasing media education and digital literacy in order to create a critical understanding of how media and digital technologies are utilized. [36,37] Finally, it is essential that public health organizations, religious leaders, and other stakeholders to continue to educate, via offline tools and conventional media, as part of multi-channels approach, so that no segment of the community is left behind. [38,39]

\section{Limitation of the study}

This study is a subject of limitations. First, the study obtained data from participants of the seminars, but it did not compare the obtained data to the data from general population in Aceh. Second, the majority of participants $(31.5 \%)$ came from the capital city of the province (Banda Aceh), and less from other regions. Therefore, a larger survey using proportional regional sampling may provide a more accurate result. Third, this study does not aim to find causation. Future research may utilize regression analysis to assess whether there is a correlation between Covid-19 knowledge and mortality, which may concur with causation.

\section{Conclusion}

Studying knowledge, attitude, and practice of a community toward Covid-19 may provide explanation of community perception on the disease. In addition to those three data, data on misperception are also crucial to assess population risk perception. It seems that low risk perception in this study might lead to population disengagement with public health measures. Therefore, the government, media, and other community stakeholders should collaborate to design health promotion approaches counteracting the hoaxes/misinformation and delivering quality information to increase positive perception, attitude and practices of the community.

Acknowledgement. The head and all members of PROKAMI Aceh for their great encouragement and hard work.

\section{References}

1. WHO, WHO (2020)

2. Reliefweb JHU, (2020)

3. K. K. RI, (2020)

4. R. Djalante, J. Lassa, D. Setiamarga, A. Sudjatma, M. Indrawan, B. Haryanto, C. Mahfud, M. S. Sinapoy, S. Djalante, I. Rafliana, L. A. Gunawan, G. A. K. Surtiari, and H. Warsilah, Prog. Disaster Sci. 6, (2020)

5. CDC, (2020)

6. E. J. Rubin, D. Ph, L. R. Baden, S. Morrissey, and D. Ph, 2021 (2020)

7. K. K. RI, (2020)

8. A. M. Tri Sakti, E. Mohamad, and A. A. Azlan, J. Med. Internet Res. 23, (2021)

9. O. Al-Wutayd, A. E. Mansour, A. H. Aldosary, H. Z. Hamdan, and M. A. Al-Batanony, Sci. Reports | 11,16769 (123AD)

10. D. E. Alagili and M. Bamashmous, J. Infect. Public Health 14, 1398 (2021)

11. F. R, Curr. Opin. Psychol. 1, 85 (2015)

12. E. Chavarría, F. Diba, M. E. Marcus, Marthoenis, A. Reuter, L. Rogge, and S. Vollmer, J. Dev. Stud. 57, 1245 (2021)

13. M. A. Fardin, Arch. Clin. Infect. Dis. 15, 15 (2020)

14. Dawn, (2020)

15. SAMAA, (2020)

16. A. Smith, J. Yarwood, and D. M. Salisbury, Vaccine 25, 3996 (2007)

17. H. J. Larson, L. Z. Cooper, J. Eskola, S. L. Katz, and S. Ratzan, Lancet 378, 526 (2011)

18. E. J. Gangarosa, A. M. Galazka, C. R. Wolfe, L. M. Phillips, R. E. Gangarosa, E. Miller, and R. T. Chen, Lancet 351, 356 (1998)

19. E. Dubé, C. Laberge, M. Guay, P. Bramadat, R. Roy, and J. Bettinger, Hum. Vaccin. Immunother. 9, 1763 (2013)

20. J. Cifuentes-Faura, Online Inf. Rev. (2020) 
21. F. D. Algahtani, M. A. Alzain, N. Haouas, K. Angawi, B. Alsaif, A. Kadri, M. A. Dkhil, M. Snoussi, and R. Zrieq, Int. J. Environ. Res. Public Health 18, 1 (2021)

22. D. Roy, S. Tripathy, S. Kumar, and N. Sharma, Asian J. Psychiatry J. (2020)

23. BPS Prov Aceh, (2020)

24. DetikHealth, (2021)

25. Dinas Kesehatan Aceh, (2021)

26. SabahD, (2020)

27. ConversationT, (2020)

28. Saleem A, (2020)

29. Wire T, $(2020)$

30. T. C. Hansel, L. Y. Saltzman, and P. S. Bordnick, Disaster Med. Public Health Prep. 14, 670 (2020)

31. L. Cori, F. Bianchi, E. Cadum, and C. Anthonj, Int. J. Environ. Res. Public Health 17, (2020)

32. E. Samadipour, F. Ghardashi, and N. Aghaei, Disaster Med. Public Health Prep. (2020)

33. A. Bhagavathula, W. A. Aldhaleei, J. R. Rahmani, M. A. Mahabadi, and D. K. Bandari, JMIR Public Heal. Surveill. (2020)

34. B. L. Zhong, W. Luo, H. M. Li, Q. Q. Zhang, X. G. Liu, W. T. Li, and Y. Li, Int. J. Biol. Sci. 16, 1745 (2020)

35. Rohrmann B, (2008)

36. Rohrmann B, (2000)

37. A. Bridgman, E. Merkley, P. J. Loewen, T. Owen, D. Ruths, L. Teichmann, and O. Zhilin, Harvard Kennedy Sch. Misinformation Rev. 1, 1 (2020)

38. M. Yu, Z. Li, Z. Yu, J. He, and J. Zhou, Curr. Issues Tour. 24, 2699 (2021)

39. L. Liu, W. Wu, and D. A. Mcentire, Int. J. Disaster Risk Reduct. (2021) 